\title{
Oligotrophic water conditions associated with organic matter regeneration support life and indicate pollution on the western side of Fernando de Noronha Island - NE, Brazil $\left(3^{\circ} \mathrm{S}\right)$
}

\author{
Elisabete de Santis Bragal*, Vitor Gonsalez Chiozzini', Gláucia Bueno Benedetti Berbel
}

\author{
${ }^{1}$ Laboratory of Biogeochemtry of Nutrients, Micronutrients and Traces in the Oceans (LABNUT) - Instituto Oceanográfico - \\ Universidade de São Paulo \\ (Praça do Oceanográfico 191 - Butantã - São Paulo - SP - 05508900 - Brazil).
}

*Corresponding author: edsbraga@usp.br

\begin{abstract}
Oligotrophy has its basis in low inorganic nutrient availability and it is generally known that in equatorial waters inorganic nutrient availability is insufficient to sustain the richness of life observed in some special places at this latitude. Thus, the understanding of the organic dissolved component role in $\mathrm{N}$ and $\mathrm{P}$ biogeochemical cycles could explain the support of the food chain in oligotrophic equatorial waters. This study was undertaken for the purpose of contributing to the knowledge of nutrient availability and the participation of dissolved organic components in the trophic conditions of an oceanic equatorial island in the South Atlantic. Water and phytoplankton were sampled on the western fringe of the Fernando de Noronha Archipelago in March 2015. Tropical oceanic conditions prevailed in this oceanic domain with high salinity $(>36.19)$ and temperatures $\left(>28.30^{\circ} \mathrm{C}\right)$. The oceanic conditions assured a high $\mathrm{pH}$ and dissolved oxygen levels $(>5.00 \mathrm{~mL}$ $\mathrm{L}^{-1}$ ). Alkalinity showed slight variations, its lowest values being associated with biological interaction. Suspended particulate matter was relatively low and its organic fraction was associated with the productive process and/or pollution contribution, which is confirmed mainly by high DON concentrations $\left(\sim 4.00 \mu \mathrm{mol} \mathrm{L}^{-1}\right)$ with an association with high total chlorophyll in the primary production process and with urea in the pollution situation. The urea content attained $2.77 \mu \mathrm{mol} \mathrm{L}^{-1}$ at a waste disposal outlet when a contamination event was observed in the region. The available inorganic nutrients showed low concentrations with an $\mathrm{N}$-ammonium average of $1.99 \pm 0.64 \mu \mathrm{mol} \mathrm{L}^{-1}$, nitrate with an average of $0.13 \pm 0.04 \mu \mathrm{mol} \mathrm{L}{ }^{-1}$, and nitrite with an average of $0.19 \pm 0.13 \mu \mathrm{mol} \mathrm{L^{-1 }}$. The DIN varied from 0.74 to $4.32 \mu \mathrm{mol} \mathrm{L}^{-1}$, principally represented by Nammonium. DOC showed values of from 53 to $109 \mu \mathrm{mol}$ $\mathrm{L}^{-1}$ and the DOC:DON ratio confirmed the organic source as being an inorganic $\mathrm{N}$ pool of oxidized organic matter and indicated that nitrogen-rich compounds are recycled faster than carbon-rich compounds. Total chlorophyll concentrations reached $0.81 \mathrm{mg} \mathrm{m}^{-3}$ and the noteworthy presence of filamentous cyanobacteria despite low inorganic nitrogen availability lead to a trophic chain initially supported with the contribution of a fixation process.
\end{abstract}

Descriptors: Nutrients, Organic compounds, Dissolved organic carbon, Urea, Pollution indicator, Oceanic island.

\section{RESUMO}

A oligotrofia tem base na baixa disponibilidade de nutrientes inorgânicos, sendo que, normalmente, em águas equatoriais, o teor de nutrientes inorgânicos não é suficiente para sustentar a riqueza de vida observada em alguns lugares especiais nesta latitude. Assim, a compreensão do papel dos componentes orgânicos dissolvidos nos ciclos biogeoquímicos do $\mathrm{N}$ e do $\mathrm{P}$ poderia esclarecer o suporte da cadeia alimentar em águas equatoriais oligotróficas. Este estudo foi realizado com o objetivo de contribuir ao conhecimento da disponibilidade de nutrientes e participação de componentes orgânicos na condição trófica das águas do entorno de uma ilha equatorial oceânica no Atlântico Sul. A água e o fitoplâncton foram amostrados na franja ocidental do arquipélago Fernando de Noronha, em março de 2015. As condições tropicais oceânicas prevaleceram neste domínio oceânico com altas salinidade $(>36,19)$ e temperatura $\left(>28,30^{\circ} \mathrm{C}\right)$. As condições oceânicas garantiram os altos valores de $\mathrm{pH}(>8,0)$ e oxigênio dissolvido $\left(>5,00 \mathrm{~mL} \mathrm{~L}^{-1}\right)$. A alcalinidade mostrou ligeiras variações com menores valores associados à interação biológica. A matéria particulada em suspensão esteve relativamente baixa e a fração orgânica foi associada ao processo produtivo e/ou contribuição da poluição, o que é confirmado principalmente por altas concentrações de $\operatorname{DON}(\sim 4,00 \mu \mathrm{mol} \mathrm{L}-1)$ associada aos maiores valores de clorofila total na situação de produção primária e, com a ureia em situação de poluição. O conteúdo de ureia atingiu $2,77 \mu \mathrm{mol} \mathrm{L} \mathrm{L}^{-1}$ em um ponto de disposição de efluentes quando um evento de contaminação foi observado na região. Os nutrientes inorgânicos disponíveis apresentaram baixas concentrações, com uma média de $\mathrm{N}$-amoniacal de $1,99 \pm 0,64 \mu \mathrm{mol} \mathrm{L} \mathrm{L}^{-1}$, nitrato com média de $0,13 \pm 0,04 \mu \mathrm{mol} \mathrm{L}^{-1}$, nitrito com média de $0,19 \pm 0,13$ $\mu \mathrm{mol} \mathrm{L}{ }^{-1}$. O DIN variou de $0,74 \mathrm{a} 4,32 \mu \mathrm{mol} \mathrm{L}^{-1}$, principalmente representado por $\mathrm{N}$-amoniacal. O DOC apresentou valores de 53 a $109 \mu \mathrm{mol} \mathrm{L}^{-1}$ e, a relação DOC:DON confirmou uma fonte orgânica para o reservatório de $\mathrm{N}$ inorgânico a partir da oxidação da matéria orgânica e indicou que os compostos ricos em nitrogênio são reciclados mais rapidamente do que os compostos ricos em carbono. As concentrações totais de clorofila atingiram $0,81 \mathrm{mg} \mathrm{m}^{-3} \mathrm{e}$ a notável presença de cianobactérias filamentosas frente à baixa disponibilidade de nitrogênio inorgânico, conduzindo a uma cadeia trófica inicialmente suportada com contribuição do processo de fixação.

Descritores: Nutrientes, Compostos orgânicos, Carbono orgânico dissolvido, Ureia, Indicador de poluição, Ilha oceânica. 


\section{INTRODUCTION}

The availability of inorganic nutrients in marine oligotrophic waters is an important factor that limiting the primary production and is essential for the organization and maintenance of the existent food chain (Dugdale, 1967a). The biogeochemical cycles of nutrients contribute to the maintenance of the life taking account the availability of nutrients in inorganic forms and also the regeneration process based on the oxidation of the organic matter present in the euphotic zone as detritus and excretion submitted to continuous sinking in the water column. The regeneration process considering the pool of dissolved organic matter coming as a part of metabolism of the ecosystem can assume an essential position in fertilization process in remote systems far from the significant terrestrial inputs. In this sense, after the synthesis of organic matter by primary producers using carbon, nitrogen and phosphorus making a part of protein, DNA, RNA, ATP and other biomolecules follows the bio-components degradation and excretion products return to inorganic forms by action of microorganisms and oxidation process. In remote regions as oceanic islands, the dissolved organic matter can play an important role in the biogeochemical cycles of nutrients to support the food chain. In the open sea, nitrate-nitrogen, a more stable and abundant form of nitrogen is controlled primarily by assimilation by phytoplankton, regeneration through the decomposition of organic matter and denitrification under anaerobic conditions (Wada and Hattori, 1991). The main sources of $\mathrm{N}$-ammonium for the marine environment are the decomposition of organic nitrogen by bacteria, the excretion of zooplankton andother animals and anoxic bacterial activity on nitrate. On the other hand, the oxidation of N-ammonium in the biogeochemical cycle, also with the help of microorganismform nitrite and nitrate and the recently discovered process of anammox (ANaerobic AMMonium OXidation), that produces $\mathrm{N}$ gas (Van De Vossenberg et al., 2008). N-ammonium is the form preferably assimilated by phytoplankton, since its ion has an optimal oxidation state for a more direct assimilation during the protein-forming process. On the other hand, the decomposition of proteins easily provide $\mathrm{N}$-ammonium to the waters. Nitrite is the intermediate compound in the oxidation-reduction reactions between ammonium and nitrate. In the case of phosphorus, phosphate is the inorganic form bioavailable for the primary production and it regeneration from organic matter occurs with more facility than for the nitrogen. Remembering the Redfield ratio (Redfield et al., 1963) to construct the organic matter in the first levels of the marine food chain, the request for $\mathrm{N}$ and $\mathrm{P}$ is $15: 1$, that put in evidence the $\mathrm{N}$ importance, crucial in oceanic waters. The biogeochemical cycles consider the organic matter decomposition, not only in particulate form, but also in dissolved organic as DOC, DON and DOP, components of DOM as important steps in the availability of nutrients. Recent works shown DON:DOP ratios in open sea with value higher than the classical Redfield's N:P ratio (Santinelli et al., 2012). Many studies of the biogeochemistry of dissolved organic carbon (DOC) and dissolved organic nitrogen (DON) in the open oceans have been published in the last two decades (Bates and Hansell, 1999; Hansell, 2002). Urea is an important component of the biogeochemical cycle of nitrogen (Antia et al., 1991; Bronk, 2002; Solomon et al., 2010). Normally, low levels of urea are found in the open sea $(0.3 \mu \mathrm{mol} \mathrm{L}-1 \mathrm{~N})$, whereas higher values (reaching 13 $\mu \mathrm{mol} \mathrm{L} \mathrm{L}^{-1} \mathrm{~N}$ ) are often observed in the coastal and estuarine zones (McCarthy, 1970). Many marine organisms excrete various nitrogen products simultaneously, as is the case of some fish which eliminate ammonium, urea and creatine in different proportions. Dissolved organic phosphorus (DOP) is available for production to both phytoplankton and bacteria (Monaghan and Ruttenberg, 1999; Kolowith et al., 2001). Therefore, it is important to quantify organic phosphorus as it is potentially available for primary production in coastal systems and in the open sea. Despite the importance of marginal seas for the cycling of dissolved organic matter (DOM) (Walsh et al., 1988; Wollast, 1991), few studies have focused on these areas (Hung et al., 2003). The data for oceanic waters are not also frequent and could be important to explain the biogeochemical cycles of nutrients in the remote oligotrophic areas which maintain an associated food chain as the case of Fernando de Noronha Archipelago.

The Fernando de Noronha Archipelago belongs to a branch of the Mid-Atlantic Ridge (Almeida, 1955; Gomes et al., 2000). The main island, also called Fernando de Noronha, is about $9 \mathrm{~km} \times 6 \mathrm{~km}$ in size, lying mainly NESW and located around $03^{\circ} 51^{\prime} \mathrm{S}$ and $32^{\circ} 25^{\prime} \mathrm{W}$. This region receives warm and salty $(>36)$ water, with oligotrophic characteristics transported by the South Equatorial Current and also comes under the influence of the Atlantic 
Equatorial Undercurrent originating off the Northeastern Brazilian Coast and flowing below and in the opposite direction to the South Equatorial Current at 60-90 m depth between $5^{\circ} \mathrm{N}$ and $5^{\circ} \mathrm{S}$ (Molinari et al., 1981; Bourlès et al., 1999; Mémery et al., 2000). The physical stratification in the upper layers is maintained by the warmer $\left(>20^{\circ} \mathrm{C}\right)$ and saltier ( $>35.5)$ water transported by the Atlantic South Equatorial Current (ASEC) (Castro Filho and Miranda, 1998; Travassos et al., 1999). High salinity values (near 37) are formed at the surface through the intense evaporation in the region known as that of the Southern band of South Equatorial Current (SSEC), fed by the Benguela Current's westwards drift ( 8 to $25^{\circ} \mathrm{S}$ off the African coast) which follows the thermocline in the $\sigma=24.5$ to 25.5 isopycnal range (Bourlès et al., 1999). The trade winds blow onto the Southeastern side of the island. The wet season lasts from February to July, the average air temperature being $25.3^{\circ} \mathrm{C}$ (Walter and Leith, 1960; Boletim do Clima, 2015). There are a few fresh-water streams in the island which remain dry during most of the year (Serafini et al., 2010). The tide is semi-diurnal with a maximum amplitude of $3.3 \mathrm{~m}$ in the spring tide and $2.0 \mathrm{~m}$ at the neap tide (Almeida, 1955). In relation to the oligotrophic conditions, low nutrient concentrations in the upper mixed layers maintain low rates of primary production with mean integrated chlorophyll concentrations of $<50 \mathrm{mg} \cdot \mathrm{m}^{-2}$ (Medeiros et al., 1999; Castro Filho et al., 2006) most of which concentrated along the pycnocline. It is noteworthy that the oceanic region is dominated by picocyanobacteria (Bröckel and Meyerhöfer, 1999; Easton et al., 1986) normally associated to the difficulties encountered in measuring the nutrient content below the detection limit of analytical methods of the oligotrophic waters in the open ocean as reported since McCarthy (1980). The benthic life is present on the slopes of Fernando de Noronha and the Rocas Atoll, seamount islands which are notable for providing support for the diverse marine life in the Western South Atlantic (Easton et al., 1986; Paiva et al., 2007; Lavelle and Mohn, 2010). The presence of the fixer organisms and the oligotrophic condition were observed. Quality of the suspended organic matter, to our knowledge, no studies have been carried at this region. This study presents an introduction to dissolved organic $\mathrm{C}, \mathrm{N}$ and $\mathrm{P}$ to contribute to the understanding the organic fraction of these nutrients in the biogeochemical cycles in oceanic areas and also to accompanied the influence of the human activities on the seawater in this remote area.

\section{MATERIAL AND METHODS}

STUDY AREA

This study was undertaken in March 2015, at the beginning of the rainy season in the Fernando de Noronha Archipelago, as a part of the CARECOS project (FAPESP 2011/50582-0 and FACEPE APQ0074-1.08/11) using the boats locally available. The analyses were made, in part, in mobile laboratories established on the island, the final ones being made in São Paulo, at the Institute of Oceanography of the University of São Paulo.

The Fernando de Noronha Archipelago consists of about 20 islands of various sizes, among them being Fernando de Noronha Island (the biggest), located in the South Equatorial Atlantic Ocean, at $03^{\circ} 52^{\prime} \mathrm{S}$ and $32^{\circ} 25^{\prime} \mathrm{W}$. This archipelago of volcanic origin belongs to a marine protected area in the National Marine Park of Fernando de Noronha. Fernando de Noronha is a summit that rises $4200 \mathrm{~m}$ above the ocean bed as one of a chain of seamounts (Almeida, 1955; 2000; 2006). The archipelago is under the influence of the Southern Equatorial Current (SEC) system which flows from East to West, near the Equator (Stramma, 1991; Silveira et al. 2000), and is subject to the passage of swell normally observed in the first three months of the year (January to March). Assunção et al. (2016) also observed a time series (2008-2015) of recorded swell events in October and December. This oceanic island has no fresh water spring, its population depending on the storage of the rainwater collected during the wet period (March to August), stored in ponds (Cat, Mulungu, Horta and Xaréu), and the desalination of marine water (http://www.ilhadenoronha.com.br) to supply the local population and the many tourists on the island. An estimated population of 2,629 (IBGE, 2010) occupies $35 \%$ of the main island, their activities being related mainly to tourism (Mendes, 2006).

\section{SAMPLING AND ANALYSES}

The water column was sampled using Nansen Hydrobios $^{\circledR}$ bottle samplers at 8 sites off the western coast of the island (Fig. 1). Temperature was obtained using a reversing protected thermometer with a precision of $\pm 0.02^{\circ} \mathrm{C}$. Salinity was measured using an inductive salinometer, with a precision of \pm 0.001 . Dissolved oxygen was determined by the Winkler method as set out in Grasshoff et al. (1983), using a potentiometric determination with Titrando, Metrohm ${ }^{\circledR}$. The method has an accuracy of 


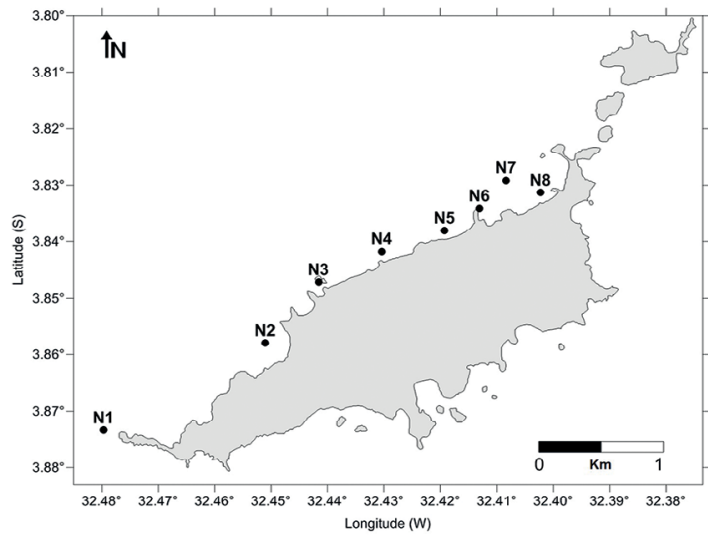

Figure 1. Localization of the sampling stations in Fernando de Noronha Archipelago, Northeastern Brazil, South Atlantic, March 2015.

$\pm 0.02 \mathrm{~mL} \mathrm{~L}^{-1}$ for levels of $2 \mathrm{~mL} \mathrm{~L}^{-1}$, and $\pm 0.04 \mathrm{~mL} \mathrm{~L}^{-1}$ for higher levels. The $\mathrm{pH}$ was assessed using a Thermo Orion pHmeter model P-210A with a glass electrode with a precision of \pm 0.01 in accordance with the recommendations set out in Aminot and Chaussepied (1983). Total alkalinity was calculated using potentiometric titration following the recommendations of Grasshoff et al. (1983). During titrations, a Methrom ${ }^{\circledR}$ Dosimat 700 doser and a Methrom $^{\circledR} 827$ pHmeter were used. Suspended particulate matter and the organic fraction were evaluated in accordance with Strickland and Parsons' (1968) recommendation for gravimetric procedures, the precision of the measurements being of $0.001 \mathrm{mg} \mathrm{L}^{-1}$. N-ammonium was determined as suggested by Solórzano (1969) with a precision of $\pm 0.02 \mu \mathrm{mol} \mathrm{L}{ }^{-1}$, nitrite and nitrate were measured using an AutoAnalyzer II Bran-Luebbe ${ }^{\circledR}$ as described by Tréguer and Le Corre (1975), with a precision of $\pm 0.02 \mu \mathrm{mol} \mathrm{L} \mathrm{L}^{-1}$. Silicate and phosphate were determined as described by Grasshoff et al. (1983) with precisions of 0.02 and $0.01 \mu \mathrm{mol} \mathrm{L}^{-1}$, respectively. The urea content was determined using the analysis described by Aminot and Kerouel (1982). Dissolved Organic Nitrogen (DON) and Dissolved organic phosphorus (DOP) were analyzed by the UV-oxidation process that determines Total Dissolved Nitrogen (TDN) and Total Dissolved Phosphorus (TDP) (Armstrong et al., 1966). DOC was measured by a high-temperature catalytic oxidation method using a Vario $\mathrm{Cube}^{\circledR}$ analyzer. Chlorophyll was assessed as recommended by Strickland and Parsons (1968).

\section{Data treatment}

Spearman's nonparametric correlation $(r s)$ was performed using the Excel $2013^{\circledR}$ software. Principal component (PCA) analyze was used with normalized data to avoid the dominance of the magnitude scales of different variables in the associations in the samples. Group analyses (clusters) were undertaken using Primer 6 (Past $\mathrm{x})^{\circledR}$ software. The spatial distribution of the parameters studied was set out using figures composed in Excel. The data were treated with a significance level $\alpha=0.05$ to identify whether there were spatial differences between the Pearson and PCA graphics.

\section{RESULTS}

The monthly rainfall on Fernando de Noronha Island in February 2015 was $49.4 \mathrm{~mm}$ (while the historical monthly average is $111 \mathrm{~mm}$ - APAC, 2017) and in March of that same year, $112.3 \mathrm{~mm}$ (while the historical monthly average is $267 \mathrm{~mm}$, APAC, 2017), thus, February and March 2015 was less rainy than expected.

In general, the presence of the salty water $(>36)$ with high temperatures $\left(>28^{\circ} \mathrm{C}\right)$ and $\mathrm{pH}$ values above 8.0 was the characteristic of tropical waters observed (Table 1), what is in keeping with the generally low precipitation in this equatorial region of ocean. The limits of variation of some abiotic data are presented in Table 1. March is normally dry in this region, but the oceanic climate is specific to this area. Although the salinity presented high values (>36) associated with the high temperatures, (Fig. 2) dissolved oxygen also presented high values, there being a significant inverse correlation between them $(r=-0.64$ $p<0.05$ ) (Fig. 3).

The limits of variation of some abiotic data are presented in Table 1. March is normally dry in this region, but the oceanic climate is specific to this area.

In detail, the hydrological parameters showed that in the oceanic equatorial zone, the values of temperature were high - attaining $29.30^{\circ} \mathrm{C}(0 \mathrm{~m})$ and $29.70^{\circ} \mathrm{C}(15 \mathrm{~m})$ at station N3 located in Dolphin Bay and $30.00^{\circ} \mathrm{C}(0 \mathrm{~m})$ in the port of Santo Antonio (N8) (Fig. 4a). In relation to salinity, high values were observed, up to 36.00 , at all points (Fig. 4b) with a minimum at the bottom at N4 (off Boldró Beach). These high values reflect the high evaporation rate of equatorial waters, which exceeded the precipitation 
Table 1. Hydrological parameters (temperature and salinity) and hydrochemical parameters (Dissolved Oxygen and pH), suspended particulate matter (SPM) and suspended particulate organic matter, optical parameters (Secchi Disk data), in Fernando de Noronha Archipelago, March 2015.

\begin{tabular}{lccccccccc}
\hline $\begin{array}{l}\text { Statistics } \\
\mathrm{n}=15\end{array}$ & $\begin{array}{c}\text { Temp. } \\
\left({ }^{\circ} \mathrm{C}\right)\end{array}$ & Salin. & $\begin{array}{c}\mathrm{DO} \\
\left(\mathrm{mL} \mathrm{L}^{-1}\right)\end{array}$ & $\%$ Sat. & $\mathrm{pH}$ & $\begin{array}{c}\text { Alkalinity } \\
\left(\mu \mathrm{mol} \mathrm{kg}^{-1}\right)\end{array}$ & $\begin{array}{c}\text { SPM } \\
\left(\mathrm{mg} \mathrm{L}^{-1}\right)\end{array}$ & $\begin{array}{c}\text { SOPM } \\
\left(\mathrm{mg} \mathrm{L}^{-1}\right)\end{array}$ & $\begin{array}{c}\text { Secchi } \\
\text { Disk } \\
(\mathrm{m})\end{array}$ \\
\hline minimum & 28.30 & 36.19 & 5.09 & 115 & 8.11 & 2227 & 15.64 & 2.77 & 2.50 \\
maximum & 30.00 & 36.30 & 5.95 & 135 & 8.19 & 2411 & 33.20 & 13.50 & 15.00 \\
Average & 29.08 & 36.25 & 5.40 & 123 & 8.15 & 2327 & 24.43 & 4.65 & 11.43 \\
SD & 0.40 & 0.03 & 0.24 & 6 & 0.02 & 56 & 4.23 & 2.45 & 4.04 \\
Median & 29.0 & 36.25 & 5.36 & 123 & 8.16 & 2346 & 23.15 & 4.08 & 12.00 \\
\hline
\end{tabular}

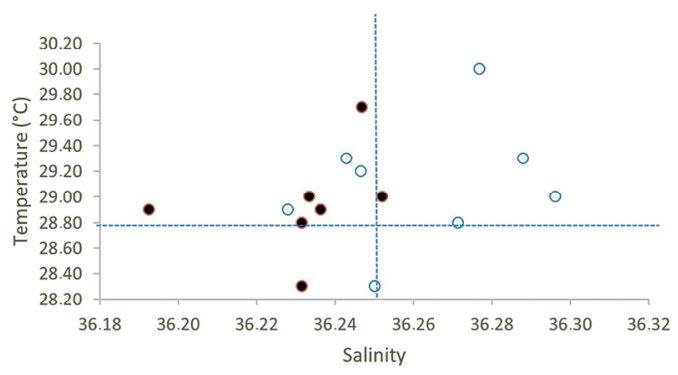

Figure 2. Temperature versus salinity on the western coast of Fernando de Noronha Island (PE-Brazil). Open circle (0m), full circle (bottom), dashed lines represent the median values of variables.

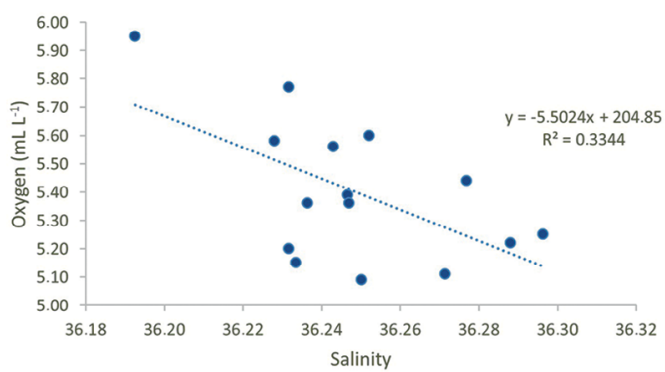

Figure 3. Correlation of salinity and dissolved oxygen in Fernando de Noronha Archipelago, in March 2015. Dashed line represent the linear regression.

during this sampling period. The highest salinity value occurred at the surface at station N5; N2 (Dolphin bay) presenting the second highest salinity value (Fig. 4b).

Dissolved oxygen values were always above $5.00 \mathrm{~mL}$ $\mathrm{L}^{-1}$ (Fig. 4c), observing that minor values were in the bottom waters, sometimes exceeding the surface concentrations. The dissolved oxygen saturation was over $100 \%$ at all points, attaining a maximum in Sapata Point (N1) at $15 \mathrm{~m}$ depth. The $\mathrm{pH}$ values were highest at the surface, decreasing slightly with depth (Fig. 4d), remarking that all them were superior to 8 , confirming the intense oceanic influence. A pH minimum (8.11) was observed at N6 (Cachorro beach), exactly where a disposal of sewage is located. The salinity in this local did not present a minimum value, but showed a tenue reduction, evidencing this island input. In the water column, suspended particulate matter showed considerable concentrations with the maximum value observed at N4 (Boldró Beach), both at the surface and at the bottom (Fig. 4e). In the cited station there was a correlation with suspended organic matter (Fig. 4f) that suggests the association of part of the suspended particulate matter with the biological material at this point.

Alkalinity showed values above $2,200 \mu \mathrm{mol} \mathrm{kg}^{-1}$, the lowest recorded value occurring in association with minimum salinity at a station under the influence of the NBUC, that received a contribution from the sNBUC, presenting minimum alkalinity at $\sim 200 \mathrm{~m}$ depth and flowing northeastwards. The SOPM showed values around $19 \%$ of the SPM and the waters showed a relatively clear waters as indicated by Secchi Disk penetration.

Observing the inorganic nitrogen compounds in this pe$\operatorname{riod}$ (March), the $\mathrm{N}$-ammonium (Fig. 5a) represented the most important $\mathrm{N}$ form in this area, and N4 (Boldró Beach) presented the lowest values in both surface and bottom waters. The concentrations of nitrite (Fig. 5b) and nitrate (Fig. 5c) were not statistically significant in absolute terms, the highest nitrate value occurring at station N8 $(0 \mathrm{~m})$ at St. Antonio port. It is noteworthy that the inorganic dissolved nitrogen (DIN) (Fig. 5d) had an important contribution of $\mathrm{N}$-ammonium. The dissolved inorganic phosphorus (Fig. 5e) in this oceanic area presented low values the highest values being found at station N2 (Golfinho Bay) and N6 (Cachorro Beach), in the bottom waters. The former site presents intensive frequency of mammals whereas at the latter, the sewage leak was pronounced. In relation to silicate (Fig. $5 \mathrm{f}$ ), the values were relatively low, showing that no significant terrestrial contribution was present, only to resuspension could an effective alteration be attributed. 

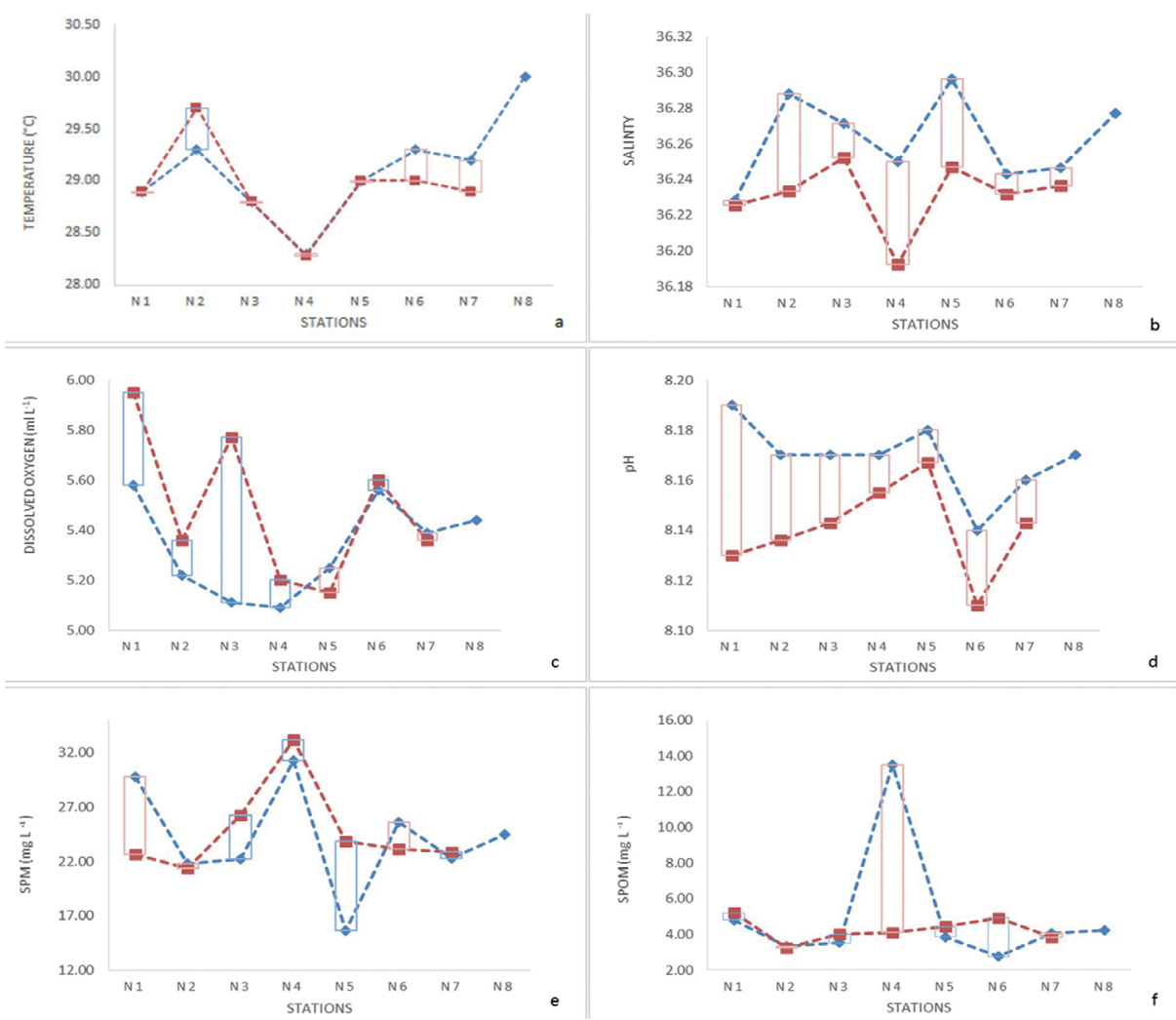

Figure 4. Distribution of temperature (a), salinity(b), dissolved oxygen(c), $\mathrm{pH}(\mathrm{d})$, suspended particulate matter (e), suspended organic matter (f) on the western side of the Fernando de Noronha Archipelago, in March 2015. (Bars indicate inversion of behavior) (Blue-surface; red-bottom waters).

The $\mathrm{N}$-ammonium and phosphate (Fig. 6a and c) showed significant respective correlation $(\mathrm{r}=0.66$ and $\mathrm{r}=0.58)$ $(p<0.05)$ that indicated the similar origin of these nutrients in this region. On the other hand, nitrate and silicate (Fig. $6 \mathrm{~b}$ and $6 \mathrm{~d})$ presented inverse behavior, with negative respective correlation $(\mathrm{r}=-0.24$ and $\mathrm{r}=-0.19),(p<0.05)$, indicating a source different from that of the former.

The Dissolved Organic Carbon (DOC) (Fig. 7a) presented values around $1 \mathrm{mg} \mathrm{L}^{-1}$ with an increase at N6, mainly at the bottom and a decrease in the direction of the port. In general, the dissolved organic phosphorus (DOP) (Fig. 7b) was low, with a slight increase at the bottom at station N6 (Cachorro Beach) associated with an increase in DOC. Dissolved organic nitrogen (DON) (Fig. 7c) corroborates this increase at the bottom at N6 and also reveals an increase at $\mathrm{N} 4$ (surface and bottom). Observing the urea signal (Fig. 7d), it is possible to attribute part of the increase in organic nitrogen at N6 to the introduction of the urea associated with the sewage outflow. In March 2015, there was a spill of domestic waste on Cachorro beach, near N6, due to the untreated sewage discharge from the Vila dos Remédios (village), as reported in a newspaper (O Estado de São Paulo, 2015).

The dissolved inorganic $\mathrm{N}$ forms constitute, as in most oligotrophic waters, the limiting factor for primary production. It could be confirmed by the low availability of inorganic nitrogen and as there is a reasonable presence of organic $\mathrm{N}$, it perhaps supports the availability of $\mathrm{N}$-ammonium both at the surface (Fig. 8a) and at the bottom (Fig. 8b), considering that it is the first regeneration product of organic matter oxidation by bacteria.

Total chlorophyll (Fig. 9) was measured during the net phytoplankton sampling, around stations N1 (Sapata Point), N2 (Golfinho Bay), N4 (Boldró beach) and N5 (Conceição beach). The chlorophyll concentrations varied from $0.18 \mathrm{mg} \mathrm{m}^{-3}$ to $0.81 \mathrm{mg} \mathrm{m}^{-3}$, the highest value being located at the surface at N4 (Fig. 9), certainly a contribution to an attractive scenario for the life support and high frequency of dolphins in this region as a result of the organized food chain. This highest value was associated with the lowest alkalinity value $(2227 \mathrm{mg})$, according to Bertini et al. (submitted). 

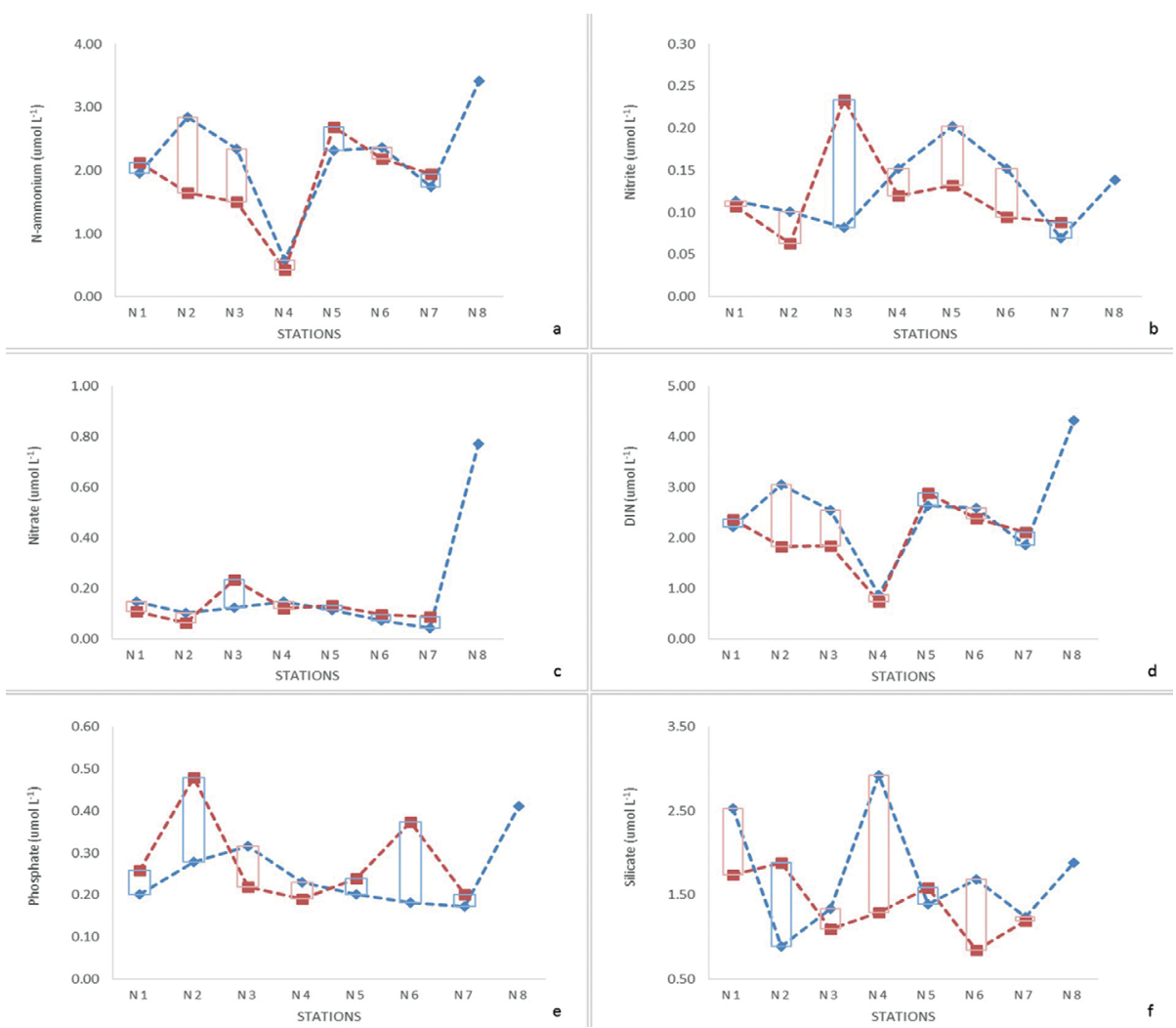

Figure 5. Distribution of N-ammonium (a), dissolved nitrite (b), dissolved nitrate (c), DIN (d), dissolved phosphate (e), dissolved silicate (f) on the western side of the Fernando de Noronha Archipelago, in March 2015. (Bars indicate inverse behavior). (Blue - surface; red - bottom water).

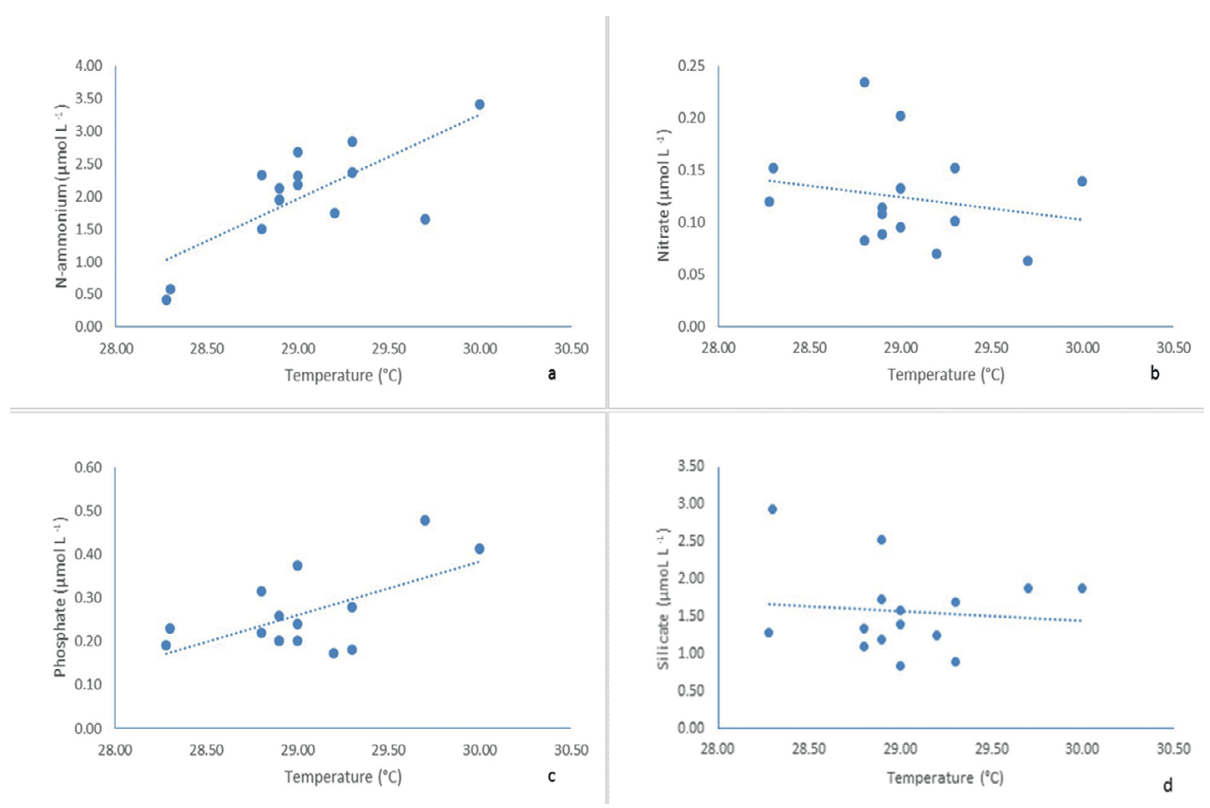

Figure 6. Correlation of temperature and nutrients: N-ammonium (a); nitrate (b); phosphate (c) and silicate (d) on Fernando de Noronha, in March 2015. Dashed lines indicate tendency. 

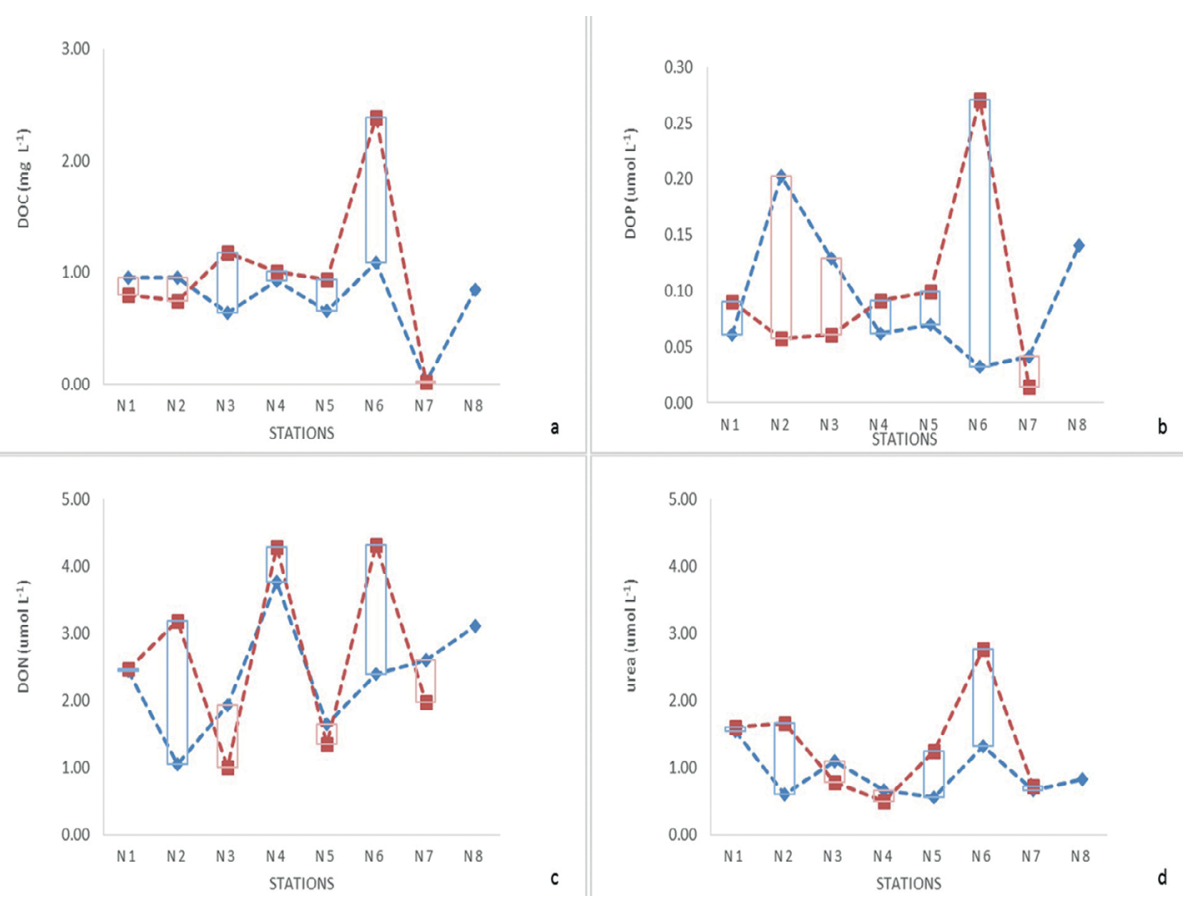

Figure 7. Distribution of DOC (a), DOP(b), DON(c) and urea(d) on the western side of the Fernando de Noronha Archipelago, in March 2015. (Bars indicate inversion of behavior.) (Blue - surface, red - bottom waters).
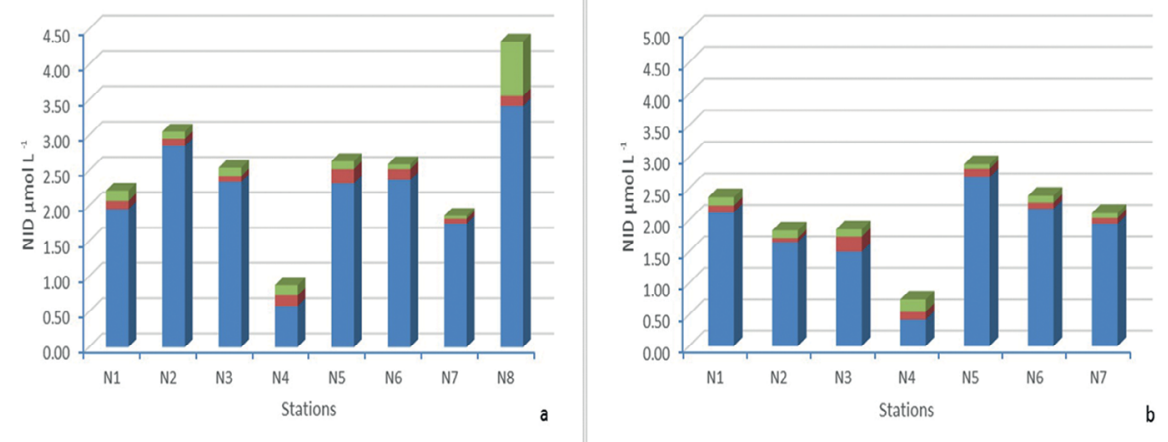

Figure 8. Accumulated concentrations of $\mathrm{N}$-ammonium (blue); nitrite (red) and nitrate (green) at the surface (a) and bottom (b), in Fernando de Noronha Archipelago, March 2015.

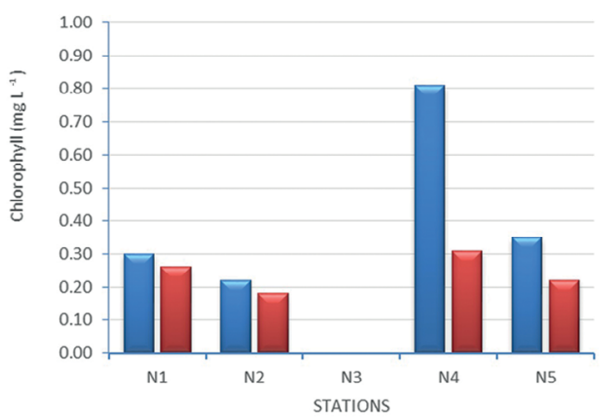

Figure 9. Distribution of total chlorophyll in Fernando de Noronha Archipelago, in March 2015. (Blue - 0m and red - bottom).
In the Archipelago, first identified here, the phytoplankton groups showed a predominance of filamentous cyanobacteria indicating the importance of the fixation process in view of the low availability of inorganic nitrogen forms, mainly $\mathrm{N}$-ammonium. This is noteworthy in relation to the support of the trophic chain under these oceanic conditions. In accordance with this sequence, the Coccolithophorids and the algae Tetraselmis sp and Chlorella sp were present in the composition of the phytoplankton collected on Fernando de Noronha. 
The presence of dissolved organic matter (DOC, DON and DOP) available in water and its relation with dissolved oxygen (Table 2) can contribute to understanding the inorganic and organic matter cycling and the regeneration process. The availability of inorganic nitrogen represent an important limitant factor to primary production and the oxidation process is a constant input to inorganic pool in this oxygenated oceanic water. In this study, DOC:DON:DOP presented reasonable values for $\mathrm{C}$ and $\mathrm{P}$ and values not enough for nitrogen.

Table 2. Values of total and organic dissolved compounds, in March 2015 (Dry season) on Fernando de Noronha-Pernambuco. (DOC=Dissolved Organic Carbon; DON=Dissolved Organic Nitrogen; DOP=Dissolved Organic Phosphorus; TDN=Total Dissolved Nitrogen; TDP=Total Dissolved Phosphorus; DO=Dissolved Oxygen).

\begin{tabular}{lc}
\hline DOC $\left(\mu \mathrm{mol} \mathrm{L}^{-1}\right)$ & $53-199$ \\
& $(84 \pm 20)$ \\
\hline DON $\left(\mu \mathrm{mol} \mathrm{L}^{-1}\right)$ & $(2.01-4.31$ \\
& $0.03-0.27$ \\
DOP $(\mu \mathrm{mol} \mathrm{L}$ & $-1)$ \\
& $(0.10 \pm 0.05)$ \\
TDN $\left(\mu \mathrm{mol} \mathrm{L}^{-1}\right)$ & $2.86-7.44$ \\
& $(4.96 \pm 0.68)$ \\
TDP $\left(\mu \mathrm{mol} \mathrm{L}^{-1}\right)$ & $0.21-0.64$ \\
& $(0.37 \pm 0.12)$ \\
DOC:DON & $20-97$ \\
& $(37 \pm 17)$ \\
DOC:DOP & $392-2,814$ \\
DO:DON & $(1,025 \pm 490)$ \\
DO:DOP & $54-256$ \\
& $(110 \pm 40)$ \\
\hline
\end{tabular}

In this study, the basis for the supply of nutrients is regeneration, as shown by the DON reservoir and the DO:DON ratio, indicating the importance of the regenerated $\mathrm{N}$ in supporting the Redfield ratio.

The PCA treatment (Fig.10) explain $42.3 \%$ of total variance and the PC1 was responsible for $22.8 \%$ and PC2 19.4\%. The variable with significant and positive correlation were: DNT (0.96), DIN (0.95) and N-ammon. (0.94), Nitrite (0.63) and DO (0.59). In relation to PC2, temperature $(0.79), \% \mathrm{OM}$ (0.68), salinity (0.56), DIP (0.53) and DOP (0.39) presented significant positive correlation coefficients, while negatives were presented by SOPM (-074), SPM (-068) and silicate $(-0.54)$. The DTN, DIN and N-ammonium presented significant correlation with PC1 and no significant with PC2.
The PCA illustrates the tuning of the organic data with the $\mathrm{N}$-ammonium showing the connection with the rapid remineralization of the organic matter in the presence of dissolved oxygen availability and also, the distance of the values N4 $(0 \mathrm{~m})$ and N6 $(10 \mathrm{~m})$ from the other data, the latter showing greater anthropogenic influence.

\section{DISCUSSION}

In equatorial waters, the variations of the sea surface temperature (SST) result from an important air-sea interaction process evident in the Tropical Atlantic Ocean, where variations of wind-induced vertical mixing and the vertical and horizontal advection of heat occur, as evidenced by several authors (Weingartner and Weisberg, 1991; Yu et al., 2010; Skielka et al., 2010). Considering this oceanic region, the entire Fernando de Noronha archipelago, it comes under the influence of the central branch of the South Equatorial Current (CSEC), flowing from E to W $\left(\approx 30 \mathrm{~cm} \cdot \mathrm{s}^{-1}\right)$ between the surface and a nominal depth of $100 \mathrm{~m}$. This influence is responsible for the presence of clear and warm waters (around $28^{\circ} \mathrm{C}$ ), with a salinity arounde 36 PSU. It is also under that of the South Equatorial Undercurrent (SEUC), flowing in the opposite direction (W to E) $\left(\approx 20 \mathrm{~cm} \cdot \mathrm{s}^{-1}\right)$, at depths of from 40 to $150 \mathrm{me}-$ ters (Easton et al., 1986; Stramma and England, 1999). The CSEC is located between the SEUC $\left(3^{\circ} \mathrm{S}-5^{\circ} \mathrm{S}\right)$ and the South Equatorial Counter Current $\left(6^{\circ} \mathrm{S}-9^{\circ} \mathrm{S}\right)$ (Peterson and Stramma, 1991; Stramma and England, 1999; Assunção et al., 2016). Weingartner and Weisberg (1991), using measurements of water temperature and velocity at the equator at $28^{\circ} \mathrm{W}$, showed that the uncoupling of the mixture layer due to wind relaxation occurs in the middle of December and traps the net surface heat flux $(Q n)$ in a thin upper layer, promoting during the following months the formation of a highly stable surface layer. This stable condition continues and is responsible for the progressive warming of the shallow mixed layer until late April/ early May when, with the strengthening of the wind, the upwelling movement and the mixing in the ocean are consequently turned on. This study was undertaken in March 2015 in an oceanic zone where no sign of upwelling was observed and an apparently stable condition was observed in the shallow water off the coast of Fernando de Noronha Island. Despite the high water temperatures, dissolved oxygen concentrations were high, always over 100\%, maybe by reason of the oceanic hydrodynamic. 


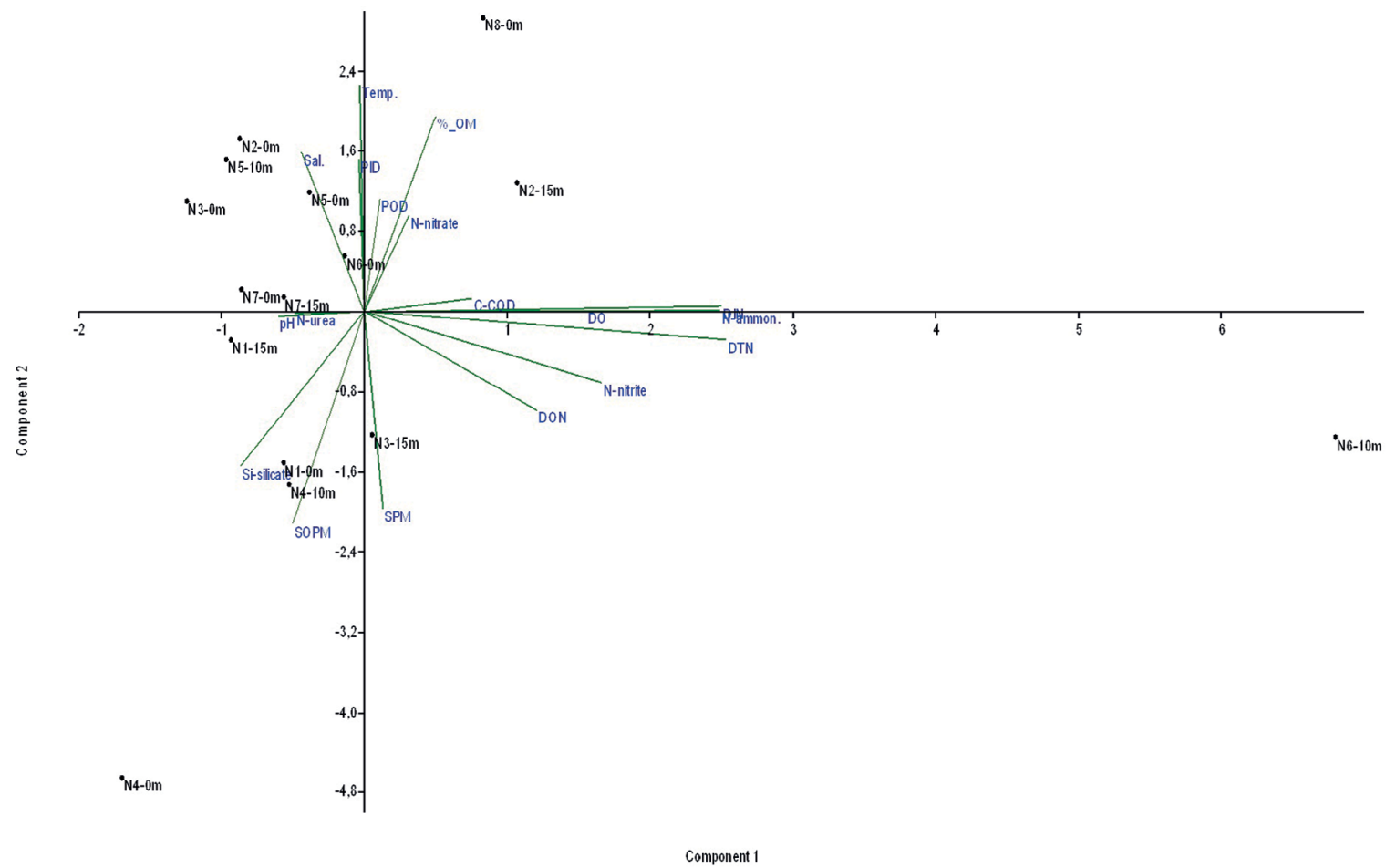

Figure 10. Data from Principal component analysis (PCA) of organic and inorganic variables of the Inner Sea coast of Fernando de Noronha Island - Pernambuco (Brazil). (A) Ordering of environmental variables, (B) ordering of samples (SPM=suspended particulate material, N-nitrite, $\mathrm{N}$-nitrate, P-phosphate, Si-silicate, DOP=Dissolved Organic Phosphorus, DON=Dissolved Organic Nitrogen, SPM=Suspended particulate matter, $\mathrm{SPOM}=$ Suspended particulate organic matter, $\mathrm{pH}$, urea, $\mathrm{N}$-ammon $=\mathrm{N}$-ammonium, $\mathrm{DO}=$ Dissolved oxygen, $\mathrm{Sal}=$ salinity, $\mathrm{T}=$ temperature,$\% \mathrm{OM}=$ $\%$ organic matter) obtained in March 2015.

The surface waters $(<20 \mathrm{~m})$ off the western coast of Fernando de Noronha, in the most touristic and highly populated area continue to be occupied by incredible life forms. The oligotrophic conditions confirm the transport of equatorial surface water by the NBUC as observed in the Equatorial Atlantic circulation models described by some authors (Molinari et al., 1981; Bourlès, et al., 1999; Mémery et al., 2000; Skielka et al., 2010). Around oceanic islands, sometimes the raising of the thermocline into the euphotic zone induced by seamount structures results in a Taylor-column, as mentioned by Boehlert and Mundy (1993), though no sign of upwelling was observed, a low level of inorganic nutrients persisting in the coastal fringe studied. Souza et al. (2013) observed a distribution of nutrients around Fernando de Noronha (1997-1998) which attained greater nitrate and nitrite values than those observed in this study, taking into consideration, however, a larger area of study. It is possible that the stationary recirculation of water that reaches the summit of the seamount could contribute to the primary production, as indicate by Genin and Boehlert (1985).
All salinity values were $\geq 36.19$, thus characterizing equatorial oceanic water, present around the archipelago with high salinity, as indicated by CITHER-1 Project (A7WOCE) near the Equator (Mémery et al., 2000). There is no evidence of fresh water input, not even near station N6 where a waste water discharge is to be observed, as is evidenced by a slight decrease in $\mathrm{pH}$ values. The dissolved oxygen values were high enough to reflect the supersaturated condition of the warm and salty waters of this region. In CITHER1 (WOCE) section A7, at station 83 (Lat. $5^{\circ} 12^{\prime} \mathrm{N}$, Long. $32^{\circ} 15^{\prime} \mathrm{W}$ ) and at station 98 of the transversal section (Long. $35^{\circ} \mathrm{W}$ ), located near Fernando de Noronha Archipelago, the salinity of the surface waters (at $100 \mathrm{~m}$ depth ) was $>36.00$, and dissolved oxygen was superior to $200 \mu \mathrm{mol} \mathrm{Kg}^{-1}$ (Group CITHER 1, 1994) that corresponds to $\sim 4.48 \mathrm{~mL} \mathrm{~L}^{-1}$.

In general, the oceanic water in tropical zones is considered oligotrophic due to the existence of the subsurface layer that creates a permanent thermocline and where the vertical transport of nutrients to the euphotic zone is minimal (Cushing, 1975). The strategy of supporting a food 
chain in oligotrophic waters is to observe the fixers associated with other phytoplankton groups at the base of the pyramid. In the case of seamounts (guyots) far from land, the divergence of current wind stress tension and the interaction of the currents with submarine relief can contribute to the mixing and renewal of the water in shallow waters (Rogers, 1994). Considering the exuberance of life in the Fernando de Noronha Archipelago and the totality of the data obtained at the sites studied, the maintenance of nutrient availability was investigated as also was the way in which dissolved organic material could play an important role in the biogeochemical nutrient cycle. The presence of equatorial surface waters was observed by virtue of their higher salinity $(>36)$ and temperature $\left(>28^{\circ} \mathrm{C}\right)$, thus presenting conditions favorable to high evaporation and also evidencing the slight influence of rainfall in this region and period thus contributing to ensure the oceanic buffer condition of the surface waters, and in this case, throughout the water column's depth, presenting $\mathrm{pH}$ of around 8. In 2014, Assunção et al. (2016), also observed high temperatures.

The inverse correlation between temperature and dissolved oxygen, even considering the high oxygen values present in the region could corroborate that the little depletion of oxygen with the increase of temperature could be associated with the gas solubility properties and with a possible use of organic matter in the oxidation process.

Assunção et al. (2016), showed that Santo Antonio port, at Fernando de Noronha Archipelago presented the highest nutrient concentrations $\left(\mathrm{NH}_{4}^{+}, \mathrm{NO}_{2}^{-}\right.$and $\left.\mathrm{NO}_{3}^{-}\right)$in 2014 and demonstrated the influence of the sewage outflow and the port activity as seen in the slight increase of nutrients associated with the low hydrodynamic activity of the port. The present study evidenced the sewage contribution at Cachorro beach not only as due to the inorganic nutrients, but also to the urea concentration. In general, this coastal fringe region presented the inorganic nutrient values characteristic of oligotrophic oceanic waters, but it is also subject to swell action promoting the release of pore water and washing the guano from birds' nests, thus occasionally fertilizing the waters, as cited by Bosman and Hockey (1986); Polis et al. (1997) and (Cozzi et al. 2014.) In the case of Golfinho Bay, the presence of dolphins in the region contributes not only with organic matter to the water column from the vomiting of the spinner dolphin population that inhabits the bay, as cited by Sazima et al. (2003), but also with the excretion of urea, thus increasing the organic nitrogenous pool.
In relation to inorganic nitrogenous compounds, oligotrophic waters normally exhibit low values of dissolved inorganic $\mathrm{N}$, their main observed form being nitrate due to its more stable form in the presence of sufficient dissolved oxygen. In general, in this study, the inorganic $\mathrm{N}$ pool presented low concentrations, with DIN (Dissolved Inorganic Nitrogen) varying from 0.74 to $4.32 \mu \mathrm{mol} \mathrm{L}^{-1}$, the highest values occurring in the internal region of the Santo Antonio port and in Golfinho Bay, regions affected by the presence of mammals and anthropogenic activities. The predominant form was $\mathrm{N}$-ammonium, accounting for more than $80 \%$ at the majority of sites, except at Boldró Beach (N4) where its levels were $66 \%(0 \mathrm{~m})$ and $57 \%$ (bottom). The predominance of $\mathrm{N}$-ammonium is a result of the ammonification due to the degradation of the particulate and dissolved organic matter present in the Inner Sea and that is involved in the regenerated $\mathrm{N}$ support for the food chain, as observed by Dugadale and Goering (1967b); Dugadale et al. (1964). This is corroborated by the DON pool, that varied from 1.04 to $4.31 \mu \mathrm{mol} \mathrm{L} \mathrm{L}^{-1}$, including low values of N-urea. DON also constitutes an important $\mathrm{N}$-source for primary production as like a level of the biogeochemical processes with the participation of microbial handle and zooplankton as like a direct source for some phytoplankton species, so an important element in this area.

In this remote area, the urea values attained $2.90 \mu \mathrm{mol}$ $\mathrm{L}^{-1}$ at N6, at the same time that a leak of sewage located off Cachorro beach had been reported on the island. Values of $<1.00$ urea-N $\mu \mathrm{mol} \mathrm{L}{ }^{-1}$ of urea were more to be expected on isolated marine islands, as was observed by Braga (1995) who recorded 0.05 and $1.71 \mu \mathrm{M}$-urea off Anchieta Island, in southern Brazil. However, the distribution of urea could occur in patches with some values slightly above $1 \mu \mathrm{mol} \mathrm{L}-1$ of urea-N revealing specifically the excretion of marine mammals, elasmobranchyos and mollusks and some fish that excrete a mixed nitrogenous products, (ammonium, urea, creatine, uric acid, aminoacids) (Braga, 2002). Urea is also the most abundant form of organic nitrogen of possible use to phytoplankton (Painter et al., 2008; Solomon et al., 2010). In Florida Bay (July) the values were 0.24 to 2.86 urea-N $\mu \mathrm{M}$, in Chesapeake Bay they were 0.27 to $1.10 \mu \mathrm{M}$ urea and on the Florida Shelf 0.32 to 0.98 (in this case the salinity varied from 34 to 36), as cited in Revilla et al. (2005). In the present study the values were $<2.00 \mu \mathrm{mol} \mathrm{L^{-1 }}$ urea except at N6, influenced by the sewage spill. The presence of an expressive marine animal life on this western coastal fringe 
(the Inner Sea) of the island, naturally favored the organic contribution to organic- $\mathrm{N}$, without to draw up a pollution situation in all points.

Even regarding inorganic nutrients, phosphate (DIP) presented values between 0.19 and $0.48 \mu \mathrm{mol} \mathrm{L}^{-1}$, a similar concentration to that observed by Assunção et al. (2016), with the highest level occurring at N2 (Golfinho Bay) which can be related to the leaching of the soil, which presents high levels of phosphorus (Nascimento, 2002). Its biogeochemical interactions adding to the mineralization of organic matter, seeing that in this region the presence of animals and birds is intensive, and dissolved organic phosphorus (DOP) attained $0.20 \mu \mathrm{mol} \mathrm{L}^{-1}$ in surface waters. Silicate presented a large range of concentrations, with values from 0.84 to $2.93 \mu \mathrm{mol} \mathrm{L}^{-1}$, confirming the minor terrestrial contribution due to the fact that the island's soil is under-saturated in silica (Almeida, 2000) and was associated with March's low rainfall in 2015 (106 mm as compared with a historical average of $267 \mathrm{~mm}$ ) (APAC, 2017). The maximum values were observed in the surface waters at Boldró Beach (N2) but, in general, values were low, maybe due mainly to the rainfall anomaly and a contribution from the effects of sediment resuspension, these values normally attaining their highest levels during the rainy season, as shown by Assunção et al. (2016), who presented a maximum value of $8.71 \mu \mathrm{mol} \mathrm{L}^{-1}$.

The TDP presented low values that reveal the leaching of the soil rich in phosphorus (Nascimento, 2002) and the decomposition of the additional organic matter from animal excreta. The dissolved organic contribution was $<30 \%$ of the total dissolved phosphorus, but enough to contribute to the inorganic reposition due to the rapid mineralization of $\mathrm{P}$. The highest values were observed in Golfinhos Bay (0m) maybe due to the contribution of organic excreta.

High values of DOC were located at Cachorro Station (N6) of $199 \mu \mathrm{mol} \mathrm{L} \mathrm{L}^{-1}$, near of sewage discharge. For other stations, DOC varied from 53 to $98 \mu \mathrm{mol} \mathrm{L} \mathrm{L}^{-1}$, typical values for tropical and temperate oceans (Santinelli et al., 2012). Fernando de Noronha Island presented low terrestrial influence due to no large rivers are present in this environment The major components of DON include urea, dissolved combined amino acids (DCAA), DFAA, proteins, nucleic acids, amino sugars, and humic substances (Bronk, 2002). Urea is account for 18 to $63 \%$ of DON concentration. DOP phosphorus is often present in concentrations up to an order of magnitude higher than DIP in oligotrophic regimes (Karl et al., 2002). However, in
Fernando de Noronha Island, DOP ranged from 6 to $42 \%$ in relation to TDP, enough to contribute to the inorganic reposition due to the rapid mineralization of $P$. The highest values were observed in Golfinhos Bay $(0 \mathrm{~m})$ maybe due to the contribution of organic excreta. Fixed $\mathrm{N}_{2}$ by cyanobacteria is the main process of source of $\mathrm{N}$ for growing phytoplankton. According with Hutchins et al. (2007) and Sañudo-Wilhelmy et al. (2004), in Trichodesmium, the $\mathrm{N}_{2}$ fixation rates were correlated to cellular $\mathrm{P}$, suggesting that $P$ limits $\mathrm{N}_{2}$ fixation. In Fernando de Noronha Island, values of DIP are higher than DOP, which do not limited for $\mathrm{N}_{2}$ fixation. However, inorganic $\mathrm{P}$ is not the only $\mathrm{P}$ source for Trichodesmium in the open ocean (Mulholland et al., 2002) other organisms can enjoy phosphate.

DOC:DON deviated the Redfield molar ratio about 5.5 times with values upper 20 . These high values may be attributed to refractory DOC from terrestrial and marine source and the same time by the low nitrate and the considerable amount of ammonium in the $\mathrm{N}$-pool. The $\mathrm{N}_{2}$ fixation by filamentous plays an important role in this region as also does the regenerated $\mathrm{N}_{2}$ as $\mathrm{N}$-ammonium, contributing to the low values of $\mathrm{C}: \mathrm{N}$ based on then $\mathrm{N}$-ammonium from both organic and inorganic sources. Nutrient limitation can influence the quality of dissolved organic matter and in high salinities environment tends to promote a stress for phytoplankton cells that start to produce mainly polysacarides that are more or less rapidly released in aquatic environment. Also, the lack of phosphorus and nitrogen explains DOC preservation, bacteria being unable to use it in such a situation (Cawet, 2002).

Recent findings in freshwater and marine environments indicate that photochemical processes can effect the release of labile $\mathrm{N}$ from dissolved organic matter (DOM). Some studies have shown that photyochemical reactions occur when DOM in marine environments is exposed to natural sunlight (Cawet, 2002).

In relation to DON:DOP molar ratio, Fernando de Noronha Island presented values that ranged 5 -142 with average of $45 \pm 35$. The value of 5 is located in surface water of Golfinho station (N3), but in major of stations and depths, the DON:DOP molar ratio presented Redfield molar ratio deviation of three -fold in average. Santinelli et al. (2012) reported high DON:DOP molar ratios in Adriatic Sea and attributed to atmospheric deposition that represents the major external source of bioavailable N. Furthermore, according with these, in the Southern Adriatic, picophytoplankton dominates the primary 
producers with a strong predominance of Synechococcus which N:P molar ratios vary between 24 and 110 (Cerino et al., 2012).

The molar ratio between dissolved oxygen, nitrate and o-phosphate in marine phytoplankton and in deep oceanic waters is almost constant $\left(\mathrm{O}_{2}: \mathrm{N}: \mathrm{P}=138: 16: 1\right.$; Redfield et al., 1963). As Laje de Santos (Braga et al., 2017), Fernando de Noronha Island presented high $\mathrm{O}_{2}: \mathrm{DON}$ and $\mathrm{O}_{2}: \mathrm{DOP}$, indicating a deficit of these nutrients.

In this region, the average DOC:DON was 5.5 times the Redfield ratio, which could explain why available organic matter is the reason for inorganic nutrients and nitrogen-rich compounds being recycled faster than carbon-rich compounds, as proposed by Sambrotto et al. (1993), as observed in another marine reserve on the southeastern coast of Brazil, where Braga et al. observed DOC:DON ratios more than 4 times higher in the Laje de Santos Marine State Park (PEMLS) (São Paulo, Brazil).

The ratio between $\mathrm{C}: \mathrm{N}$ and $\mathrm{N}: \mathrm{P}$ total forms is low and in that of DOC:DON the value increases $(>20)$ indicating the organic contribution confirmed by the low nitrate and the considerable amount of ammonium in the N-pool. The $\mathrm{N}$ fixation by filamentous cyanobacteria mentioned by other authors (in preparation) plays an important role in this region as also does the regenerated $\mathrm{N}$ as $\mathrm{N}$-ammonium, contributing to the low values of $\mathrm{C}: \mathrm{N}$ based on the ammonium contribution from both organic and inorganic sources. The abundance of Trichodesmium is generally limited to oligotrophic waters with ideal between $20^{\circ} \mathrm{C}-30^{\circ} \mathrm{C}$ ). Breitbarth et al. (2007) showed that the optimal Thermic condition is between 24 and 30 (near to the temperatures observed in this study). At these temperatures the growing rate is max and it corresponds to the maximum of mmol of $\mathrm{N}_{2}$ fixed permol of POC per hour.

The C:P ratios above 100 (Redfield et al., 1963) were observed, also considering the organic forms (DOC:DOP) which seemed to confirm the relatively high availability of $\mathrm{P}$ in the water explained by the organic contribution (guano and the excreta of aquatic animals) added to the availability attributed to the soil contribution previously noted by Rocha et al. (2005). Cachorro Beach and Golfinho Bay presented the highest values of organic components, probably associated with the influence of sediment resuspension and its biogenic source, natural and anthropogenic contributions to the organic dissolved material in the water column.

In general, oligotrophic water was present in this region, with enough $\mathrm{P}$ to support the primary production associated with $\mathrm{N}$-ammonium as the main $\mathrm{N}$-support. Maybe another mechanism contributes to the primary production common in oceanic oligotrophic areas, such as the fixation process. This could be the explanation for the profusion of life in this area. Organic matter is probably an important source of autochthonous recycling material, shown by the different ratios between the organic forms and also of those with the dissolved oxygen availability as favoring the oxidation process.

The increase in the oxidation of organic matter due to the rise in temperature could be acting in the regeneration of $\mathrm{N}$-ammonium and phosphate and showed significant respective correlation $(\mathrm{r}=0.66$ and $\mathrm{r}=0.58)(p<0.05)$ that indicated the similar origin of these nutrients in this region.

In relation to chlorophyll and phytoplankton, the maximum level of chlorophyll was observed at the surface at N4 (Boldró beach), the region having an exuberant marine life supported by the food chain. Cordeiro et al. (2013), studying the chlorophyll maximum at seamounts near the Rocas atoll, attributed to $\mathrm{N}$-ammonium availability the fertilization observed as it was evidenced in this study at $\mathrm{N} 4$, local where the lowest alkalinity was present indicating a potential sequestration of $\mathrm{CO}_{2}$, association that mentioned by (Balch et al., 2005).

The $\mathrm{N}$-ammonium that represents the preferred form in the assimilation process, but that it also results from the rapid regeneration of organic nitrogenous materials, which might be the main process supporting the primary production in this region far from the continent and the terrestrial input of $\mathrm{N}$, that would explain other recycling processes in the maintenance of the food chain.

To reinforce the biological data, Easton et al. (1986) characterized the benthic marine organisms concerned as in some ways coincident with the points made in this study and in relation to macro-algae, they registered the presence of blue-green algae and calcareous crusts in the intertidal, lower intertidal and infralittoral zones, with red Melibesioidea. Boldró beach (N4) presented a Vermitidae/ Melobesioidea reef platform on the infralittoral fringe which sheltered a more varied fauna. The sub-tidal zone, in Carrero da Pedra Bay (near N 2), was predominantly covered by macroalgae (Easton et al., 1986) as also was Sapata Point.

\section{CONCLUSION}

Considering that the archipelago is formed by the peaks of volcanic seamounts and the ocean floor is located 
at about $4200 \mathrm{~m}$ depth, the islands possibly constitute a barrier that could induce upwelling processes in the insular shelf water as has been observed on another island as described by Thomson (1981), however, this upwelling effect was not observed on the internal fringe of the island during this investigation. The local process of nutrient input and remobilization and the remineralization of the organic fraction of nutrients could be considered to constitute an important source of material to support the primary production including the fixation process at the beginning of the chain food. The oligotrophy based only on inorganic nutrients is not enough to account for the limitation of life based on primary production in a remote oceanic area. The biogeochemical cycles of nutrients giving importance to $\mathrm{N}$ and $\mathrm{P}$ organic forms and the microbial role influenced by temperature and dissolved oxygen availability lie behind regeneration actions. The fixation process is also important when $\mathrm{N}$-inorganic forms need to be supplied to maintain the initial phases of the food chain in remote areas with particular organization. In warmer oceanic water, faster nutrient turnover in the surface mixed layer is essential for the functioning of oligotrophic ecosystems. The support of $\mathrm{N}$-ammonium for primary production and its source in organic $\mathrm{N}$ was clearly evidenced in this region; on the other hand, the concentration of urea in this remote area made human influence on the water quality evident and the need for a rigid monitoring plan for waste water in the Fernando de Noronha Archipelago clear. Organic matter and the inorganic nutrients released, added to the bacterioplankton remineralization of dissolved organic matter, can sustain phytoplankton and heterotrophic organisms in oceanic waters.

\section{ACKNOWLEDGEMENTS}

The authors wish to thank: FAPESP -2011/50582-0 and FACEPE APQ-0074-1.08/11 for their financial support within the FAPESP/FACEPE/ANR program; our colleagues at the Federal University of Pernambuco, particularly Dr Manuel Flores Montes; Caio Hirakwaua, Ana Maria de Souza and João Carlos Cattini Maluf, IOUSP students, for their sampling and analytical support during the campaign; Dra Flavia Saldanha for her personal communication, and Hannah Leite and Leonardo Bertini for their information, respectively, on phytoplankton characteristics and alkalinity.

\section{REFERENCES}

ALMEIDA, F. F. M. 1955. Geologia e Petrologia do Arquipélago de Fernando de Noronha. Monografia. Rio de Janeiro, Departamento Nacional de Produção Mineral. Divisão de Geologia e Mineralogia. (Rio de Janeiro), 1-181.

ALMEIDA, F. F. M. 2000. Arquipélago de Fernando de Noronha. In: SCHOBBENHAUS, C., CAMPOS, D. A., QUEIROZ, E. T., WINGE, M. \& BERBERT-BORN, M. (eds.) Sítios geológicos e paleontológicos do Brasil. Brasília: Comissão Brasileira de Sítios Geológicos e Paleobiológicos-SIGEP/Departamento Nacional de Produção Mineral-DNPM/Serviço Geológico do Brasil-CPRM.

ALMEIDA, F. F. M. 2006. Ilhas oceânicas brasileiras e sua relação com a tectônica atlântica. Terrce Didática, 2, 3-18.

AMINOT, A. \& CHAUSSEPIED, M. 1983. Manuel des Analyses Chimiques en Milieu Marin, Brest CNEXO, CEDEX.

AMINOT, A. \& KEROUEL, R. 1982. Automatic-determination of urea in sea-water - A sensible method using diacetilmonoxime. Canadian Journal of Fisheries and Aquatic Sciences, 39, 174-183.

ANTIA, N. J., HARRISON, P. J. \& OLIVEIRA, I. 1991. The role of dissolved nitrogen in phytoplankton nutrition, cell biology and ecology. Phycologia, 30,1-89.

ARMSTRONG, F. A., WILLIAMS, P. M. \& STRICKLAND, J. D. H. 1966. Photo-oxidation of organic matter in sea water by ultra-violet radiation, analytical and application. Nature, 211, 481-463.

APAC (Agência Pernambucana de Águas e Clima). [cited 2017 May 2]. Available from: www.apac.pe.gov.br

ASSUNÇÃO, R. V., SILVA, A. C., MARTINS, J. \& FLORES-MONTES, M. 2016. Spatial-temporal variability of the thermohaline properties in the coastal region of Fernando de Noronha Archipelago, Brazil. Journal of Coastal Research, 75, 512-516.

BALCH, W. M., GORDON, H. R., BOWLER, B. C., DRAPEAU, D. T. \& BOOTH, E. S. 2005. Calcium carbonate measurements in the surface global ocean based on Moderate-Resolution Imaging Spectroradiometer data. Journal of Geophysical Research, 110, C07001. DOI: 10.1029/2004JC002560 
BATES, N. R. \& HANSELL, D. A. 1999. A high resolution study of surface layer hydrographic and biogeochemical properties between Chesapeake Bay and Bermuda. Marine Chemistry, 67, 1-16.

BOEHLERT, G. W. \& MUNDY, B. C. 1993. Ichthyoplankton assemblages at seamounts and oceanic islands. Bulletin of Marine Science, 53, 336-361.

BOLETIM DO CLIMA. 2015. Síntese climática - Figura 13 - Quantis mensais para Zona da Mata e Litoral. Boletim do Clima, 3.

BOSMAN, A. L. \& HOCKEY, P. A. R. 1986. Seabird guano as a determination of rocky intertidal structure. $M a$ rine Ecology Progress Series, 32, 247-257.

BOURLÈS, B., GOURIOU, Y. \& CHUCHLA, R. 1999. On the circulation in the upper layer of the western equatorial Atlantic. Journal of Geophysical Research, 104, 21151-21170.

BRAGA, E. S. 1995. Distribuição sazonal da ureia na região de Ubatuba $45^{\circ} 04^{\prime} \mathrm{W}$ e $23^{\circ} 32^{\prime} \mathrm{S}$. Publicação Especial do Instituto Oceanográfico de São Paulo Paulo, 11, 91-98.

BRAGA, E. S. 2002. Bioquímica Marinha: Efeitos da poluição nos processos bioquímicos. $2^{\mathrm{a}} \mathrm{ed}$, São Paulo, Fundespa.

BRAGA, E. S., BERBEL, G. B. B., CHIOZZINI, V. G. \& ANDRADE, N. C. G. 2017. Dissolved organic nutrients $(\mathrm{C}, \mathrm{N}, \mathrm{P})$ in seawater on the continental shelf in the Southwestern South Atlantic with emphasis State Marine Park of Laje de Santos (SMPLS) - São Paulo - Brazil. Brazilian Journal of Oceanography, 65, 614627.

BREITBARTH, E., OSCHLIES, A. \& LAROCHE, J. 2007. Physiological constraints on the global distribution of Trichodesmium: effect of temperature on diazotrophy. Biogeosciences, 4, 53-61.

BRÖCKEL K. \& MEYERHÖFER, M. 1999. Impacts of the Rocks of São Pedro and São Paulo upon the quantity and quality of suspended particulate organic matter. Archive of Fishery and Marine Research, 47, 223-238.

BRONK, D. A. 2002. Dynamics of organic nitrogen. In: HANSELL, D. A. \& CARLSON, C. (eds.) A Biogeochemistry of Marine Dissolved Matter. San Diego: Academic Press.

CASTRO FILHO, B. M. \& MIRANDA, L. B. 1998. Physical oceanography of the western Atlantic continental shelf located between $40^{\circ} \mathrm{N}$ and $34^{\circ} \mathrm{S}$. In: ROBINSON, A. R. \& BRINK, K. H. (eds.) The Sea - The Global Coastal Ocean - Regional Studies and Synthesis. New York: John Wiley \& Sons, Inc.
CASTRO FILHO, B., BRANDINI, F. P., PIRES-VANIN, A. M. S. \& MIRANDA L. B. 2006. Multidisciplinary Oceanographic Processes on the Western Atlantic Continental Shelf between $4^{\circ} \mathrm{N}$ and $34^{\circ} \mathrm{S}$. In: ROBINSON, A. R. \& BRINK K. H. (eds.) The Sea, Vol. $14 A$ The Global Coastal Ocean: Interdisciplinary Regional Studies and Syntheses. Harvard: Harvard University Press.

CAWET, G. 2002. DOM in coastal Zone. In: HANSELL, D. A. \& CARLSON, C. A. (eds.) Biogeochemistry of Marine Dissolved Matter. San Diego: Academic Press.

CAWET, G., DOM in the Coastal Zone. Em: HANSELL, D.A., CARLSON, C.A. eds.,. Biogeochemistry of Marine Dissolved Organic Matter. Academic Press, New York,. NY, 579-609. 2002.

CERINO, F., BERNARDI AUBRY, F., COPPOLA, J., LA FERLA, R., MAIMONE, G., SOCAL, G. \& TOTTI, C. 2012. Spatial and temporal variability of pico-, nano- and microphytoplankton in the offshore waters of the Southern Adriatic Sea (Mediterranean Sea). Continental Shelf Research, 44, 94-105. DOI: 10.1016/j.csr.2011.06.006

CORDEIRO, T. A., BRANDINI, F. P., ROSA, R. S. \& SASSI, R. 2013. Deep Chlorophyll maximum in Western Equatorial Atlantic - How does it Interact with islands slopes and seamounts? Marine Science, 3, 30-37.

COZZI, S., MISTARO, A., SPARNOCCHIA, S., COLUGNATI, L., BAJT, O. \& TONIATTI, L. 2014. Anthropogenic loads and biogeochemical role of urea in the Gulf of Trieste. Science of the Total Environmet, 493, 271-281.

CUSHING, D. H. 1975. Marine Ecology and Fisheries, Cambridge, Cambridge University Press.

DUGDALE, R. C. 1967a. Nutrient limitation in the sea: dynamics, identification and significance. Limnology and Oceanography, 12, 685-695.

DUGDALE, R. C. \& GOERING, J. J. 1967b. Uptake of new and regenerated forms of nitrogen in primary productivity. Limnology and Oceanography, 12, 196-206.

DUGDALE, R. C., GOERING, J. J. \& RYTHER, J. H. 1964. High nitrogen fixation rates in the sargasso sea and the arabian sea. Limnology and Oceanography, 9, 507-510.

EASTON, V. R., MIGOTTO, A. E., OLIVEIRA FILHO, E. C., RODRIGUES, S. A., \& FREITAS, J. C. 1986. Vertical distribution of benthic organisms on rocky costs of the Fernando de Noronha Archipelago (Brazil). Boletim do Instituto Oceanográfico, 34, 37-53. 
O ESTADO DE SÃO PAULO. 2015. http://brasil.estadao. com.br/noticias/geral,esgoto-vaza-e-fecha-praia-em-noronha, 1656446.

GENIN, A. \& BOEHLERT, G. W. 1985. Dinamics of temperature and chlorophyll structures above a seamount: an oceanic experiment. Journal of Marine Research, 43, 907-924.

GOMES, P. O., GOMES, B. S., PALMA, J. J. C., JINNO, K. \& SOUZA, J. M. 2002. Ocean-continent transition and tectonic framework of the oceanic crust at the continental margin off NE Brazil: Results of LEPLAC Project. In: MOHRIAK, W. U. \& TALWANI, M. (eds.) Atlantic Rifts and Continental Margins. Washington: AGU.

GRASSHOFF, K., EHRHARDT, M. \& KREMELING, K. 1983. Methods of Seawater Analysis, $2^{\text {nd }}$ ed, Weinhein, Verlag Chemie.

Group CITHER 1; BOURLÈS, B., CORRE, D., DANGU, F. GOURIOU, Y. \& OUDOT, C. 1994. Recueil de coupes verticales. In: Campagne CITHER 1 à bord du N.O. 1'Atalante (2 janvier-19 mars 1993): recueil de données. Cayenne: ORSTOM. 159 p

HANSELL, D.A., 2002. DOC in the global ocean carbon cycle. In: Hansell, D.A., Carlson, C.A. (Eds.), Biogeochemistry of Marine Dissolved Organic Matter. Academic Press, San Diego, pp. 685-716.

HUNG, J. J., CHEN, C. H., GONG, G. C., SHEU, D. D. \& SHIAH, F. K. 2003. Distributions, stoichiometric patterns and cross-shelf exportsof dissolved organic matter in the East China Sea. Deep Sea Research Part II: Topical Studies in Oceanography, 50, 1127-1145.

HUTCHINS, D. A., FU, F. X., ZHANG, Y., WARNER, M. E., FENG, Y., PORTUNE, K., BERNHARDT, P. W. \& MULHOLLAND, M. R. 2007. $\mathrm{CO}_{2}$ control of Trichodesmium $\mathrm{N}_{2}$ fixation, photosynthesis, growth rates, and elemental ratios: Implications for past, present, and future ocean biogeochemistry. Limnology and Oceanography. 52, 1293-1304.

IBGE (Instituto Brasileiro de Geografia e Estatística). 2015. Censo 2010. Available from: https://censo2010. ibge.gov.br/ [cited 2015 Jan 21].

KARL, D. M., MICHAELS, A., BERGMAN, B., CAPONE, D., CARPENTER, E., LETELIER, R., LIPSCHULTZ, F., PAERL, H. W., SIGMAN, D., \& STAHL, L. 2002. Dinitrogen fixation in the world's oceans. Biogeochemistry, 57/58, 47-98.
KOLOWITH, L. C., INGALL, E. D. \& BENNER, R. 2001. Composition and cycling of marine organic phosphorus. Limnology and Oceanography, 46, 309320.

LAVELLE, J. W. \& MOHN, C. 2010. Montains in the sea: motion, commotion, and biophysical connections at the deep ocean seamounts. Oceanography, 23, 90-103.

MCCARTHY, J. J. 1970. A urease method for urea in seawater. Limnology and Oceanography, 15, 309-313.

MEDEIROS, C., MACEDO, S. J., FEITOSA, F. A. N. \& KOENING, M. L. 1999. Hydrography and phytoplankton biomass and abundance of North-east Brazilian waters. Archive of Fishery and Marine Research, 47, 133-151.

MÉMERY, L., ARHAN, M., ALVAREZ-SALGADO, X. A., MESSIAS, M. J., MERCIER, H., CASTRO, C. G. \& RIOS, A. F. 2000. The water masses along the western boundary of the south and equatorial Atlantic. Progress in Oceanography, 47, 69-98.

MENDES, L. D. F. 2006. História natural dos amborés e peixes-macaco (Actinopterygii, Blennioidei, Gobioidei) do Parque Nacional Marinho do Arquipélago de Fernando de Noronha, sob um enfoque comportamental. Revista Brasileira de Zoologia, 23, 817-823.

MOLINARI, R. L., VOITURIEZ, B. \& DUNCAN, P. 1981. Observations in Subthermocline undercurrent of equatorial South Atlantic Ocean:1978-1980. Oceanologica Acta, 4, 451-456.

MONAGHAN, E. J. \& RUTTENBERG, K. C. 1999. Dissolved organic phosphorus in the coastal ocean: reassessment of available methods and seasonal phosphorus profiles from the Eel River shelf. Limnology and Oceanography, 44, 1702-1714.

MULHOLLAND, M. R., FLOGE, S., CARPENTER, E. J. \& CAPONE, D. G. 2002. Phosphorus dynamics in cultures and natural populations of Trichodesmium spp. Marine Ecology Progress Series, 239, 45-55.

NASCIMENTO, C. W. A. 2002. Fertilidade dos solos da Ilha de Fernando de Noronha. Reunião Brasileira de Fertilidade do Solo e Nutrição de Plantas-FERTBIO. In: Reunião Brasileira de Fertilidade do Solo e Nutrição de Plantas - FERTBIO, 25, Rio de Janeiro.

PAINTER, S. C., SANDERS, R., WALDRON, H. N., LUCAS, M. I. \& TORRES-VALDES, S. 2008. Urea distribution and uptake in the Atlantic Ocean between 50 degrees N and 50 degrees S. Marine Ecology Progress Series, 368, 53-63. 
PAIVA, P. C., YOUNG, P. S. \& ECHEVERRÍA, C. A. 2007. The Rocas atoll, Brazil: a preliminary survey of the crustacea and polychaete fauna. Arquivos do $\mathrm{Mu}$ seu Nacional, 65, 241-250.

PETERSON, R. G. \& STRAMMA, L. 1991. Upper-level circulation in the South Atlantic Ocean. Progress in Oceanography, 26, 1-73.

POLIS, G. A., HURD, S. D., JACKSON, C. T. \& PIÑERO, F. S. 1997. El niño effects on the dynamics and control of an island ecosystem in the Gulf of California. Ecology, 78, 1884-1897.

REDFIELD, A. C., KETCHUM, B. H. \& RICHARDS, F. A. 1963. The influence of organismo on the composition of the seawater. In: HILL, M. N. (ed.) The Sea. New York: John Wiley.

REVILlA, M., ALEXANDER, J. \& GLIBERT, P. M. 2005. Urea analysis in coastal waters: comparison of enzymatic and direct methods. Limnology and Oceanography Methods, 3, 290-299.

ROCHA, A. T., DUDA, G. P., NASCIMENTO, C. W. A. \& RIBEIRO, M. R. 2005. Phosphorus fractionation and evaluation of available-P extractors in soils of Fernando de Noronha Island. Revista Brasileira de Engenharia Agrícola e Ambiental, 9, 178-184.

ROGERS, A. D. 1994. The biology of seamounts. Advances in Marine Biology, 30, 305-350. DOI: 10.1016/ S0065-2881(08)60065-6

SAMBROTTO, R. N., SAVIDGE, G., ROBINSON, C., BOYD, P., TAKAHASHI, T., KARL, D. M., LANGDON, C., CHIPMAN, D., MARRA, J. \& CODISPOTI, L. 1993. Elevated consumption of carbon relative to nitrogen in the ocean surface. Nature, 363, 248-250.

SANTINELLI, C., IBELLO, V., LAVEZZA, R., CIVITARESE, G. \& SERITTI, A., 2012. New insights into C, $\mathrm{N}$ and $\mathrm{P}$ stoichiometry in the Mediterranean Sea: The Adriatic Sea case. Continental Shelf Research, 44, 8393.

SAÑUDO-WILHELMY, S. A., TOVAR-SANCHEZ, A., FU, F. X., CAPONE, D. G., CARPENTER, E. J. \& HUTCHINS, D. A. 2004. The impact of surface-adsorbed phosphorus on phytoplankton Redfield stoichiometry. Nature, 432, 897-901.

SAZIMA, I., SAZIMA, C. \& SILVA, J. M. 2003. The cetacean offal connection: feces and vomits of spinner dolphins as a food source for reef fishes. Bulletin of Marine Science, 72, 151-160.
SERAFINI, T. Z., FRANÇA, G. B. \& ANDRIGUETTO-FILHO, J. M. 2010. Ilhas oceânicas brasileiras: biodiversidade conhecida e sua relação com o histórico de uso e ocupação humana. Revista da Gestão Costeira Integrada, 10, 281-301.

SILVEIRA, I. C. A., SCHMIDT, A. C. K., CAMPOS, E. J. D., GODOI, S. S. \& IKEDA, Y. 2000. A corrente do Brasil ao largo da costa leste brasileira. Revista Brasileira de Oceanografia, 48, 171-183.

SKIELKA, U.T., SOARES, J. \& OLIVEIRA, A. P. 2010. Study of the equatorial Atlantic Ocean mixing layer using a one-dimensional turbulence model. Brazilian Journal of Oceanography, 58, 57-69.

SOLOMON, C. M., COLLIER, L. K., BERG G. M. \& GLIBERT, P. M. 2010. Role of urea in microbial metabolism in aquatic systems: a biochemical and molecular review. Aquatic Microbial Ecology, 59, 67-88.

SOLÓRZANO, L. 1969. Determination of ammonia in natural waters by phenol hydrochloride method. Limnology and Oceanography, 14, 799-801.

SOUZA, C. S., LUZ, J. A. G., MACEDO, S., MONTES, M. J. F. \& MAFALDA, P. JR. 2013. Chlorophyll and nutrient distribution around seamounts and islands of the tropical South-western Atlantic. Marine \& Freshwater Research, 64,168-184.

STRAMMA, L. 1991. Geostrophic transport of the South Equatorial Current in the Atlantic. Journal of Marine Research, 49, 281-294.

STRAMMA, L. \& ENGLAND, M. 1999. On the water masses and mean circulation of the South Atlantic Ocean. Journal of Geophysical Research Oceans, 104, 20863-20883.

STRICKLAND, J. D. H. \& PARSONS, T. R. 1968. A Pratical Handbook of Seawater Analysis. Bulletin 167, $2^{\text {nd }}$ ed. Ottawa, Fisheries Research Board of Canada.

THOMSON, J.M., 1981. MUGILIDAE. In W. FISCHER, G. BIANCHI AND W.B. SCOTT (eds.) FAO species identification sheets for fishery purposes. Eastern Central Atlantic; fishing areas 34, 47 (in part). Department of Fisheries and Oceans Canada and FAO. Vol. 3. pag. var. http://www.fao.org/docrep/009/ag419e/ag419e00. htmVol.VII

TRAVASSOS, P., HAZIN, F., ZAGAGLIA, J., ROCHA, R. A. \& SCHOBER, J. 1999. Thermohaline structure around seamounts and islands of Northeast Brazil. Archive of Fishery and Marine Research, 47, 211-222. 
TRÉGUER, P. \& LE CORRE, P. 1975. Manuel d'analysis des sels nutritifs dans l'eau de mer, $2^{\text {ème }} \mathrm{e}$. Brest, Université de Bretagne Occidentale.

VAN DE VOSSENBERG, J. RATTRAY, J. E., GEERTS, W., KARTAL, B., VAN NIFTRIK, L., VAN DONSELAAR, E. G., SINNINGHE DAMSTÉ, J. S., STROUS, M. \& JETTEN, M. S. M. 2008. Enrichment and characterization of marine anammox bacteria associated with global nitrogen as production. Environmental Microbiology, 10, 3120-3129.

YU, J., FOSTER, G. L., ELDERFIELD, H., BOECKER, W. \& CLARK, E. 2010. An evaluation of benthic foraminiferal B/ $\mathrm{Ca}$ and $\mathrm{d} 11 \mathrm{~B}$ for deep ocean carbonate ion and $\mathrm{pH}$ reconstructions. Earth Planetary Science Letters. 293, 114-120.

WADA, E. \& HATTORI, A. 1991. Nitrogen in the Sea: forms, abundances, and rate processes, Boca Raton, CRC Press.
WALSH, J. J., BISCAYE, P. E. \& CSANADY, G. T. 1988. The 1983-1984 shelf edge exchange processes (SEEP)-I experiment: hypotheses and highlights. Continental Shelf Research, 435-456.

WALTER, H. \& LEITH, H. 1960. Klimadiagramm weltatlas. Jena, Gustav Fisher Verlag.

WEINGARTNER, T. J. \& WEISBERG, R. H. 1991. On the annual cycle of equatorial upwelling in the central Atlantic Ocean. Journal of Physical Oceanography. 21, 68-82.

WOLLAST, R. 1991. The coastal organic carbon cycle: fluxes, sources, and sinks. In: MANTOURA, R. F. C., MARTIN, J. M. \& WOLLAST, R. (eds.) Ocean Margin Processes in Global Change. Hoboken: John Wiley and Sons. 